\title{
PERKEMBANGAN PEMANFAATAN IKAN PELAGIS KECIL MENGGUNAKAN PUKAT CINCIN SIBOLGA DI PERAIRAN BARAT SUMATERA PADA TAHUN 2003
}

\author{
Tuti Hariati"
}

\begin{abstract}
ABSTRAK
Tingkat pengusahaan ikan layang (Decapterus russelli) dan banyar (Rastrelliger kanagurta) yang tertangkap di perairan barat Sumatera pada tahun 1995 sudah tinggi masing-masing 0,65 dan 0,75. Laju tangkap per hari per kapal ikan layang, banyar, dan kembung pada 5 daerah penangkapan pukat cincin di perairan barat Sumatera dari tahun 1992 sampai 1994 cenderung turun. Beberapa kapal pukat cincin Sibolga menjajaki daerah penangkapan baru di sepanjang pantai barat Sumatera sampai perairan Banda Aceh. Penelitian perikanan pukat cincin yang berpangkalan di Sibolga pada periode tahun 2003-2004 dilakukan untuk memperoleh informasi mengenai perkembangan dan status pukat cincin saat ini. Data hasil tangkapan dan upaya kapal pukat cincin sampel dikumpulkan dari tangkahan sedangkan data karakteristik, operasional kapal diperoleh dari wawancara serta panjang jenis ikan pelagis kecil dominan diperoleh dari pengukuran langsung. Adanya perkembangan dimensi kapal, jumlah kapal dan alat bantu (rumpon) pada tahun 2003 telah menyebabkan munculnya 2 jenis jaring yaitu pukat rapat dan pukat jarang serta perluasan daerah penangkapan terutama ke luar paparan (laut dalam). Hasil tangkapan pukat rapat pada tahun 2003 didominasi 3 jenis ikan layang (D.russelli, D. macrosoma, dan D. macarellus), sedangkan pukat jarang didominasi oleh 3 jenis ikan pelagis besar yaitu cakalang, tuna, dan tongkol. Kisaran panjang ikan layang, layang biru, banyar, dan bentong yang tertangkap pukat rapat pada tahun 2003 umumnya lebar dan nilai $I_{c}$ relatif tinggi, terutama ikan banyar, akibat perluasan daerah penangkapan ke perairan yang lebih dalam yang diduga telah mendekati daerah pemijahan.
\end{abstract}

\section{ABSTRACT: The development of small pelagic resource by purse seine fishery of Sibolga in the waters of western Sumatera in year 2003. By: Tuti Hariati}

The exploitation rate of both indian scad (Decapterus russelli) and indian mackerel (Rastrelliger kanagurta) caught using Sibolga's purse seine in west Sumatera waters in 1995 were high, 0.65 and 0.75 respectively. CPUE per vessel per day of scads and mackerels in the five fishing grounds tended to decrease. Several Sibolga purse seiners tried to find new fishing grounds along west Sumatera coast through Banda Aceh waters. A research on purse seine fishery of Sibolga was conducted in the period of 2003-2004, to get some information on the status and it's development. Catch and effort data were collected from a private landing place, dimension of vessels, operational aspects, and lengths of several dominant pelagic species were obtained by interview and measurement. In 2003, the development of vessels size, number of vessels, and the use of rumpon beside halogen lamps had made two kinds of purse seine net i.e. the 1 inch and the 34 inch of purse seines, and also the extention of fishing grounds to the waters off the shelf (deeper sea). Fishes caught by the 1 inch purse seine were dominated by the three scads (D.russelli, D. macrosoma, and D. macarellus) while by the 3-4 inch were dominated by skipjack (Katsuwonus pelamis), tuna (Thunnus albacares), as well as little tunas (Auxis thazard and Thunnus tonggol). Both range of the length and $I_{c}$ value of scads, indian mackerel (Rastrelliger kanagurta) and bigeye scad (Selar crumenophthalmus) caught by the 1 inch purse seine in 2003 were wide and high expecially indian mackerel, since the development of fishing grounds into the deeper waters probably close to the spawning ground.

KEYWORD: $\quad$ small pelagic, purse seine, west of Sumatera waters

\section{PENDAHULUAN}

Kegiatan perikanan laut yang berlangsung di perairan barat Sumatera (Samudera Hindia) tepatnya di perairan wilayah Sumatera Barat dan Sumatera Utara berpusat di beberapa lokasi pendaratan seperti di Padang, Air Bangis, dan Sibolga. Menurut Sudjastani (1983) dari tahun 1974 sampai tahun 1976 produksi tahunan perikanan laut di perairan barat Sumatera rata-rata 65 ribu ton, dua pertiga bagian di antaranya merupakan produksi ikan pelagis kecil yang dihasilkan dari jenis-jenis alat tangkap tradisional seperti payang, pukat pantai, dan jaring insang yang

\footnotetext{
•) Peneliti pada Balai Riset Perikanan Laut, Jakarta
}

beroperasi di perairan dekat pantai. Hasil pengkajian stok pada tahun 1976 oleh Sudjastani (1983) menunjukkan bahwa nilai MSY ikan pelagis kecil 43 ribu ton sedangkan produksi ikan pelagis kecil saat itu baru mencapai 27 ribu sehingga tingkat eksploitasi dinyatakan masih rendah. Namun, dengan digunakannya alat tangkap pukat cincin yang menggantikan alat tangkap tradisional sejak tahun 1980 , yang menyerap kurang lebih 3.000 orang nelayan diduga telah terjadi perkembangan pemanfaatan sumber daya ikan pelagis kecil yang pesat. Merta et al., (1998) menduga, tingkat pemanfaatan sumber daya ikan tersebut sudah jenuh. 
Dari hasil penelitian tahun 1992 sampai tahun 1995, kapal pukat cincin umumnya berukuran antara 20 dan 58 GT dengan modus pada kisaran 30,039,9 GT (setara dengan kapal pukat cincin ukuran sedang di perairan utara Jawa), menggunakan mesin in board rata-rata 100 PK. Setiap kapal dilengkapi dua buah palka yang masing-masing berkapasitas 2 ton, fish finder, dan radio. Alat bantu yang digunakan adalah lampu merkuri dengan daya listrik 15-150 kwh. Jaring pukat cincin umumnya berukuran panjang $800 \mathrm{~m}$, dalam $60 \mathrm{~m}$ dan ukuran mata jaring terkecil pada bagian kantung 1 inci. Jumlah kapal pukat cincin pada tahun 1995 (115 unit), turun dari tahun 1992 (128 unit), karena beberapa pengusaha pukat cincin beralih ke bubu lukah untuk menangkap jenis-jenis ikan karang. Tempat pendaratan tersebar di 25 tangkahan milik perusahaan swasta.

Daerah penangkapan pukat cincin yang pada awalnya hanya di perairan barat kota Sibolga (Teluk Tapanuli dan sekitarnya), telah meluas menjadi lima daerah penangkapan yaitu perairan barat Sibolga, Tapanuli Tengah (Pulau Sorkam, Barus), Tapanuli Selatan, Aceh Selatan (Kepulauan Banyak dan Singkil), dan perairan yang berbatasan dengan wilayah Sumatera Barat (sekitar Pulau Pini dan Kepulauan Batu). Kelima daerah penangkapan tersebut masih terletak di perairan paparan dan di sekitar pulau-pulau kecil dengan kedalaman 50-100 m (Gambar 1).

Berdasarkan jumlah rata-rata hari efektif tiap tahun kapal pukat cincin pada kelima daerah penangkapan, perairan Aceh Selatan merupakan daerah penangkapan yang paling banyak didatangi (13.242 hari). Laju tangkap ikan pelagis kecil di perairan Aceh Selatan selama tahun $1992-1994$ rata-rata $413,1 \mathrm{~kg}$ per hari per kapal (Hariati, 2001).

Hasil tangkapan pukat cincin Sibolga tahun 19901994 terdiri dari kelompok pelagis kecil (48-60\%), ikan campuran $(20-28 \%)$, pelagis besar $(12-15 \%)$, layur dan alu-alu (3-7\%), dan ikan karang (1-12\%). Pada saat ini terjadi perubahan persentase jenis ikan hasil tangkapan, sebagai dampak perkembangan dimensi kapal yang membawa akibat pada perluasan daerah penangkapan baik di paparan maupun ke arah laut dalam di lepas pantai.

Ikan pelagis kecil yang tertangkap dari perairan barat Sumatera pada tahun 1990-1994 terdiri atas jenis-jenis ikan layang (Decapterus russelli dan $D$. macrosoma), banyar (Rastrelliger kanagurta), kembung (R.brachyosoma), bentong (Selar

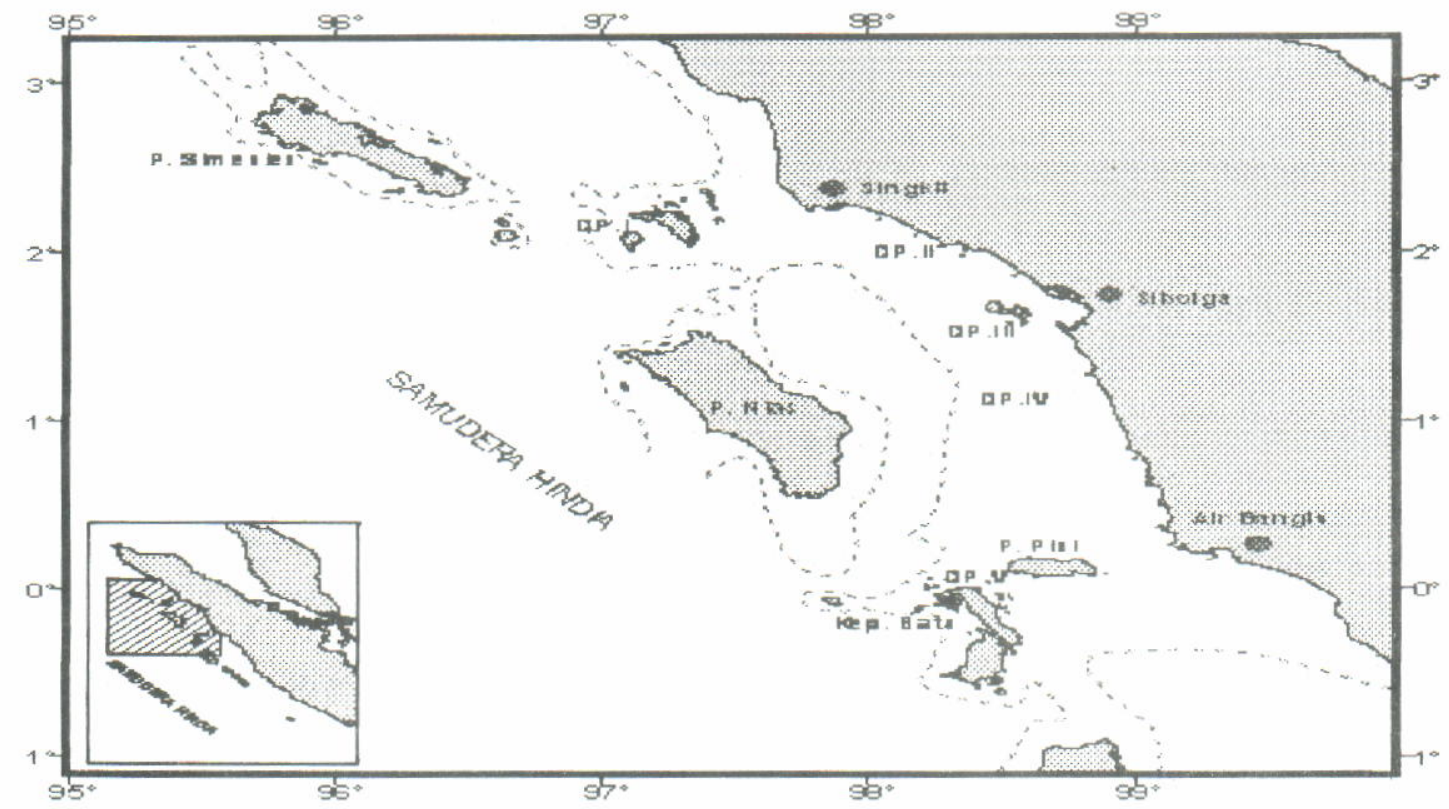

Gambar 1. Lima Daerah Penangkapan (DP) pukat cincin Sibolga di perairan barat Sumatera pada tahun 1992-1994.

Figure 1. The five fishing grounds of Sibolga's purse seiners in the waters of western Sumatera during year 1992-1994.

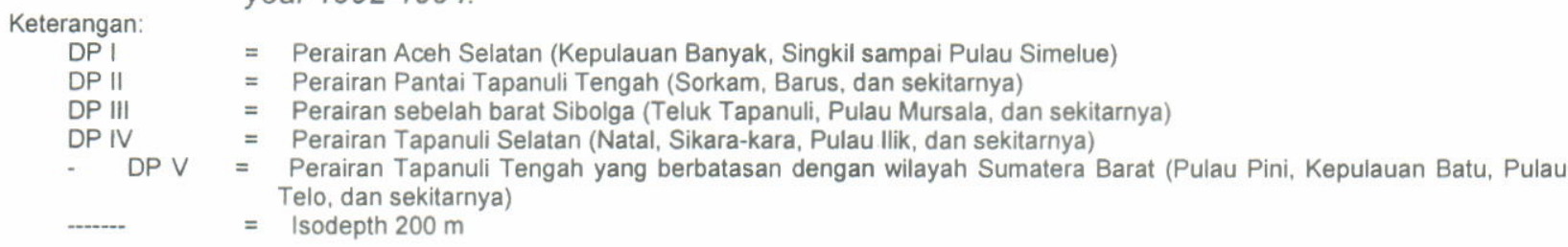


crumenophthalmus), siro (Ambligaster sirm), tembang (Sardinella gibbosa), dan japuh (Dussumieria acuta). Di antara jenis-jenis ikan pelagis kecil tersebut, ikan layang $(12,5 \%)$, banyar $(11,3 \%)$, dan kembung $(13,1 \%)$ merupakan jenis-jenis yang dominan sedangkan ikan tembang $(6,2 \%)$, bentong $(4,5 \%)$, siro $(3,1 \%)$, dan japuh $(3,3 \%)$ masing-masing di bawah $10 \%$.

Hasil analisis frekwensi panjang ikan layang (Decapterus russelli) dan ikan banyar (Rastrelliger kanagurta) yang tertangkap di perairan Aceh selatan menunjukkan bahwa tingkat pengusahaan ikan layang sudah tinggi $(E=0,75)$, hampir mencapai tingkat pengusahaan maksimal $\left(E_{\max }=0,80\right.$ ) (Hariati et al., 2001a). Tingkat pengusahaan (E) ikan banyar sudah mencapai 0,65 , hampir mencapai $E_{\max }=0,66$ (Hariati et al., 2001b). Pemanfaatan ikan layang dan banyar di perairan barat Sumatera pada tahun 1995 diduga sudah fully exploited sehingga penambahan jumlah upaya perikanan pukat cincin di perairan paparan sepanjang pantai barat wilayah Sumatera Utara tidak dianjurkan. Hasil analisis kelimpahan (CPUE) menunjukkan bahwa CPUE layang, banyar, dan kembung pada tiap daerah penangkapan tahun 19921995 cenderung turun (Hariati, 2001). Oleh karena itu, sejak tahun 1994 beberapa kapal pukat cincin Sibolga menjajaki daerah penangkapan yang lebih jauh antara lain ke arah barat daya dan selatan yaitu ke perairan Pariaman (Sumatera Barat), Bengkulu, dan Lampung, serta ke arah utara yaitu ke perairan Banda Aceh.

Setelah tahun 1995 belum ada informasi lebih lanjut mengenai perikanan pukat cincin Sibolga. Penelitian perikanan pelagis kecil di perairan barat Sumatera yang berpangkalan di Sibolga pada periode tahun 2003 dimaksudkan untuk mengetahui perkembangan terkini pukat cincin.

\section{BAHAN DAN METODE}

\section{Tempat dan Waktu}

Penelitian perikanan pelagis kecil di perairan barat Sumatera dilakukan di salah satu dari 25 tempat peridaratan (tangkahan) pukat cincin di Sibolga dalam periode 2003-2004.

\section{Metode}

\section{a. Pengumpulan data}

Hasil tangkapan sekitar 9 kapal pukat cincin sampel selama tahun 2003 diamati untuk memperoleh data jumlah dan jenis-jenis ikan pelagis kecil hasil tangkapan kapal contoh serta jumlah upaya (trip dan hari di laut). Aspek-aspek perikanan lainnya seperti daerah penangkapan dan karakteristik armada (dimensi kapal, mesin, dan jaring) serta aspek perikanan lainnya diperoleh dari hasil wawancara dan pengamatan langsung di lapangan.Untuk pendugaan hasil tangkapan total kapal pukat cincin di Sibolga dan sekitarnya, jumlah trip kapal pukat cincin selama tahun 2003 dikumpulkan dari Kantor Administrasi Pelabuhan Sibolga. Data sebaran frekwensi panjang ikan pelagis kecil diperoleh dari hasil pengukuran pada bulan Januari sampai Agustus 2004. Data tingkat kematangan gonad ikan pelagis kecil jenis betina diperoleh dari pengamatan terhadap contoh 50 spesimen ikan banyar, layang pipih, dan bentong pada bulan Oktober 2003 dan bulan April 2004.

\section{b. Analisis}

Data hasil tangkapan per jenis ikan dari kapalkapal contoh yang didaratkan tiap hari disusun dan ditabulasi menurut bulan, dari Januari sampai dengan Desember 2003 terdiri atas:

1. Hasil tangkapan menurut jenis ikan dari kapal sampel tiap bulan (A).

2. Jumlah trip (B) dan jumlah hari di laut efektif $(C)$ kapal contoh disusun tiap-tiap bulan, juga jumlah trip kapal pukat cincin total di Sibolga dan sekitarnya (D)

3. Hasil tangkapan rata-rata per trip (T): A dibagi $B$.

4. Hasil tangkapan per hari (indeks kelimpahan): $A$ dibagi $C$.

5. Dugaan hasil tangkapan total tiap bulan adalah $T$ dikalikan $\mathrm{D}$.

6. Data Sebaran frekwensi panjang ikan layang, banyar, kembung, dan bentong bulan Januari sampai Agustus 2004 diakumulasi untuk menghitung nilai-nilai $\mathrm{I}_{c}$ dari rumus ogif selektifitas dan untuk membuat kurva logistik (Sparre \& Venema, 1999).

\section{HASIL DAN BAHASAN}

Pada tahun 2003 karakteristik armada dan operasional pukat cincin Sibolga mengalami perkembangan antara lain dalam komposisi ukuran dan jumlah kapal serta daerah penangkapan pukat cincin di Sibolga.

\section{Komposisi Ukuran dan Jumlah Kapal, serta Dimensi Jaring}

Setelah melakukan pencarian daerah penangkapan yang baru dan lebih jauh dari pangkalannya, armada pukat cincin Sibolga mengembangkan dimensi kapal. Dari kisaran bobot kapal 17-58 GT dengan modus 30,039,9 GT (Gambar 2) pada tahun 1992 berkembang menjadi 20-130 GT dengan mudus 80,0-89,9 GT (Gambar 3) pada tahun 2003. Persentase perbandingan jumlah kapal berdasarkan ukurannya. Pada tahun 2003 menjadi 15\% untuk kapal berukuran sedang (20-40 GT) dan $85 \%$ untuk kapal pukat cincin besar (50-130 GT).

Untuk pengoperasian armada di lepas pantai perairan barat Sumatera, penggunaan kapal pukat cincin di atas $50 \mathrm{GT}$ diduga lebih cocok dan tangguh dalam mengarungi ombak yang besar dan arus yang deras selama berhari-hari. 


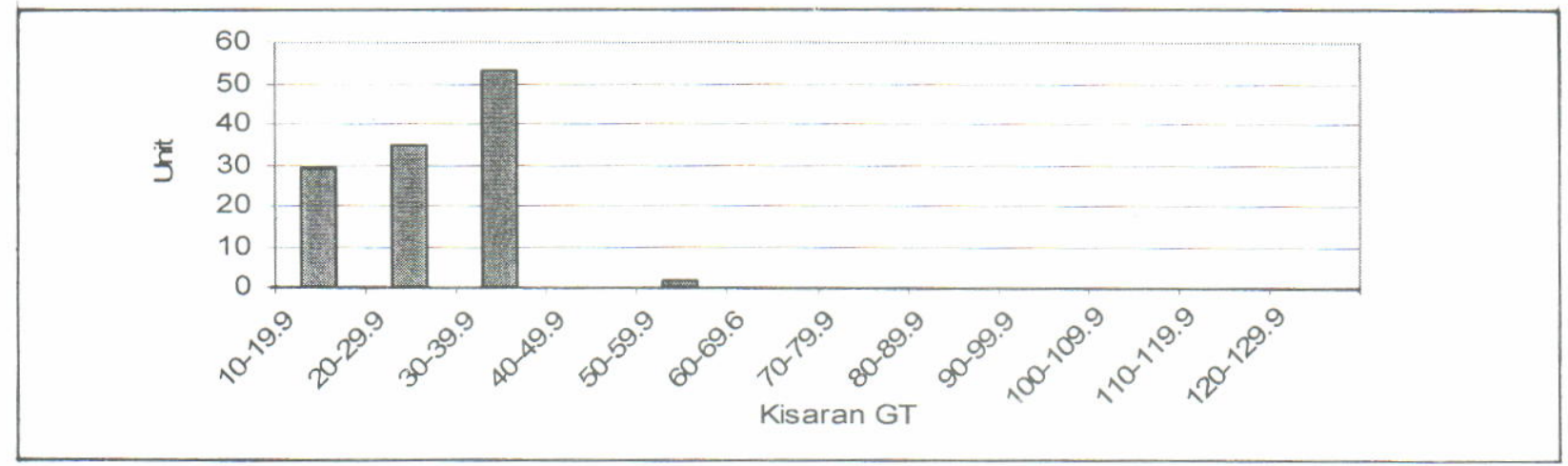

Gambar 2. Komposisi ukuran kapal pukat cincin di Sibolga tahun 1992.

Figure 2. S S Size composition of purse seiners in Sibolga in the year of 1992.

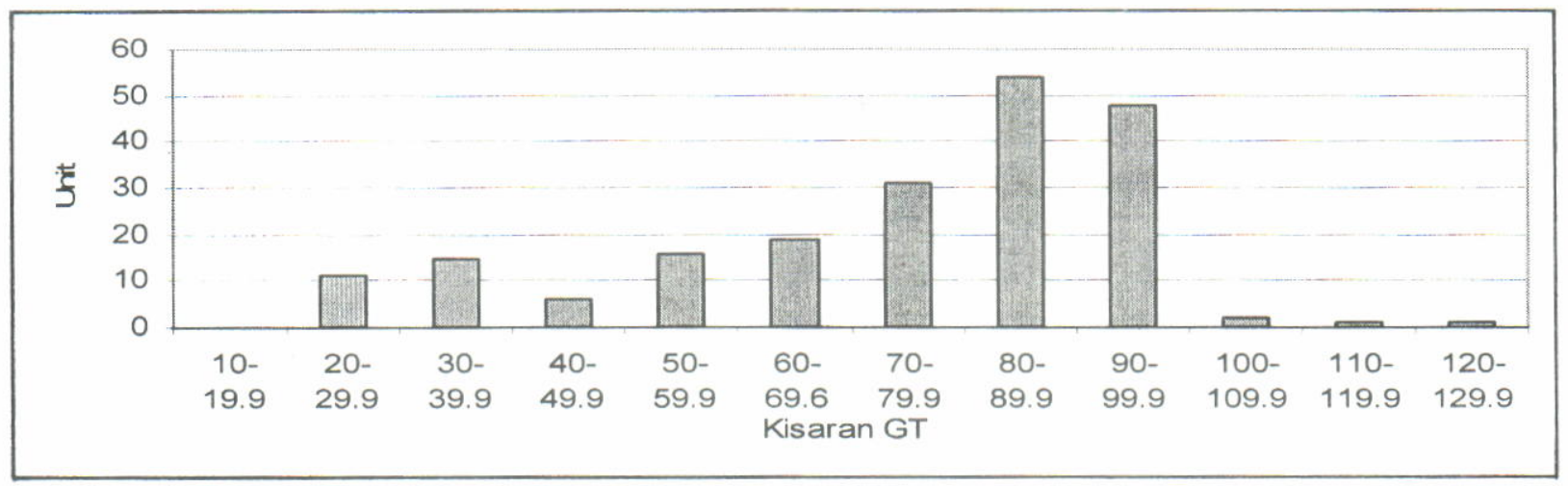

Gambar 3. Komposisi ukuran kapal pukat cincin di Sibolga tahun 2003.

Figure 3. Size composition of purse seiners in Sibolga in the year of 2003.

Kapal pukat cincin terbuat dari kayu, dilengkapi dengan mesin penggerak yang terdiri dari mesin induk (Nissan RE 10) dan mesin bantu (TS Yanmar 115 PK). Hasil tangkapan ditempatkan dalam palka yang berjumlah 10 buah dengan kapasitas masing-masing 3 ton. Selain jaring, alat lain yang dibawa di antaranya kompas atau GPS, radio komunikasi, dan fish finder.

Dari tahun 1985 sampai 1992 terjadi peningkatan jumlah kapal pukat cincin yang disusul dengan penurunan dari tahun 1993 sampai 1995 (Gambar 4), bagan perahu, jaring insang, pancing, dan bubuh lukah oleh beberapa pengusaha pukat cincin untuk menangkap ikan teri dan jenis-jenis ikan karang. Kegiatan tersebut berlangsung hingga berakibat terhadap penurunan penangkapan dengan lukah di perairan barat Sumatera Utara.

Pada tahun 1996 jumlah kapal kembali meningkat sampai dengan tahun 2000 karena keberhasilan armada pukat cincin dalam upaya perluasan daerah penangkapan ke luar wilayah Sumatera Utara,

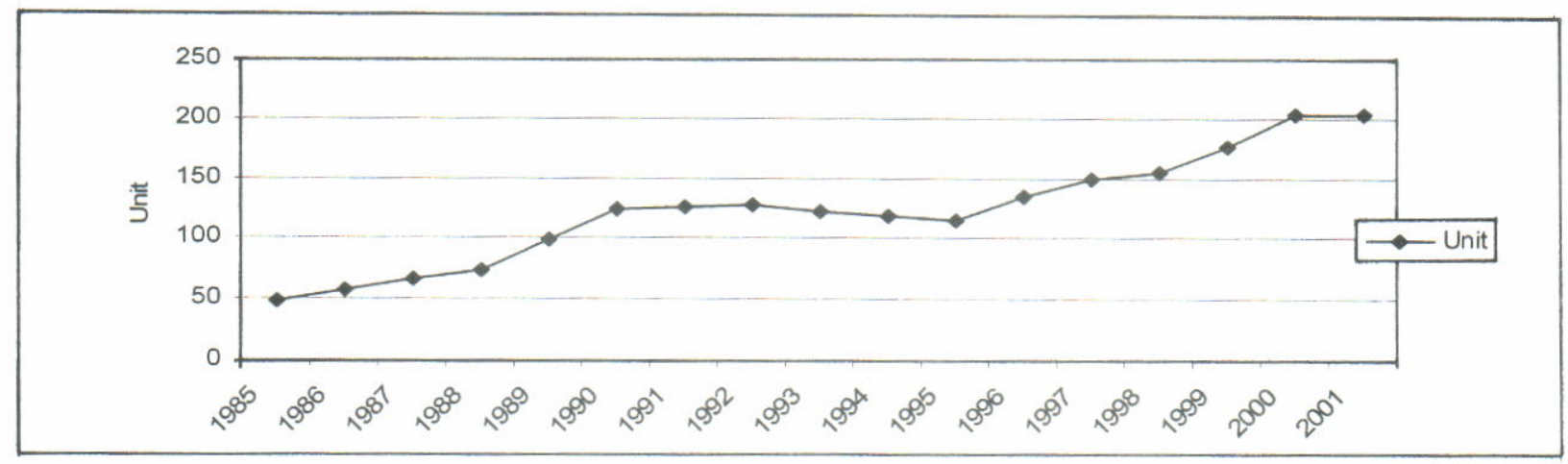

Gambar 4. Jumlah kapal pukat cincin Sibolga tiap tahun.

Figure 4. Annual number of purse seiners in Sibolga. 
dengan menggunakan kapal yang berukuran lebih besar dari sebelumnya (tahun 1990-an). Dari tahun 2001 sampai dengan 2003 jumlah kapal cenderung tetap.

Dimensi jaring pukat cincin yang digunakan untuk menangkap ikan pelagis kecil umumnya tidak berubah yaitu panjang $700 \mathrm{~m}$ dan dalam $60 \mathrm{~m}$ serta ukuran mata jaring 1 inci. Pada tahun 2003 telah dibuat jaring untuk menangkap ikan cakalang, panjang $1.000 \mathrm{~m}$ dan dalam 100 m dengan mata jaring sekitar 3-4 inci. Dengan demikian tiap kapal memiliki 2 jenis jaring pukat cincin yaitu pukat rapat untuk menangkap ikan pelagis kecil dan pukat jarang untuk menangkap ikan pelagis besar. Dalam operasi penangkapan, jika tidak ada gerombolan ikan pelagis kecil berkumpul di rumpon, kapal lalu digerakkan menuju lokasi penangkapan ikan cakalang untuk mengoperasikan pukat jarang. Alat bantu dalam pengoperasian pukat rapat selain 30 buah lampu halogen dengan daya tiap lampu 1.500 Watt (dinamo $50 \mathrm{kwh}$, Mitsubishi putar 16, $300 \mathrm{PK})$, juga rumpon yang dipasang di daerah penangkapan.

\section{Daerah Penangkapan}

Perluasan daerah penangkapan ikan pelagis kecil yang dilakukan pada tahun 1994 ke seluruh paparan yang sempit di sepanjang pantai barat Sumatera diduga kurang efisien, baik dari segi biaya maupun hasil dan perolehannya. Akhirnya perluasan daerah penangkapan ikan pelagis kecil dilakukan ke arah lepas pantai yang masih terletak di wilayah Sumatera Utara sampai perbatasan dengan Sumatera Barat dan perairan Aceh Selatan di mana terdapat cekungancekungan laut dalam dan pulau-pulau kecil.

Pada tahun 2003 pukat rapat hanya dioperasikan di 3 daerah penangkapan (Gambar 5) yaitu DP V perairan perbatasan wilayah Sumatera Utara dan Sumatera Barat (perairan Pulau Pini dan Kepulauan Batu), DP IV-perairan Tapanuli Selatan (sekitar Pulau llik), dan DP I perairan Aceh Selatan (sekitar Kepulauan Banyak dan Singkil.

Dua daerah penangkapan yang terletak di perairan pantai dekat Sibolga yaitu perairan barat Sibolga (DP III) dan perairan Tapanuli Tengah (DP II) pada tahun 2003 tidak lagi ditempuh oleh kapal yang berukuran besar. Kedua daerah penangkapan tersebut terletak di perairan pantai dan masih dekat dengan pangkalannya di Sibolga, sehingga kapal besar tidak diizinkan lagi beroperasi di jalur tersebut. Dari tertangkapnya ikan kembung ( $R$. brachyosoma) muda (nama lokal: tandeman, berukuran 13-14 cm), anak kembung (nama daerah: jara, berukuran 5-7 $\mathrm{cm}$ ) serta ikan layang (D.russelli) muda (nama lokal: sarnet net, berukuran $10-13 \mathrm{~cm}$ ) oleh pukat cincin pada periode 1990-1994 dapat diketahui bahwa DP II dan DP III merupakan daerah asuhan ikan kembung

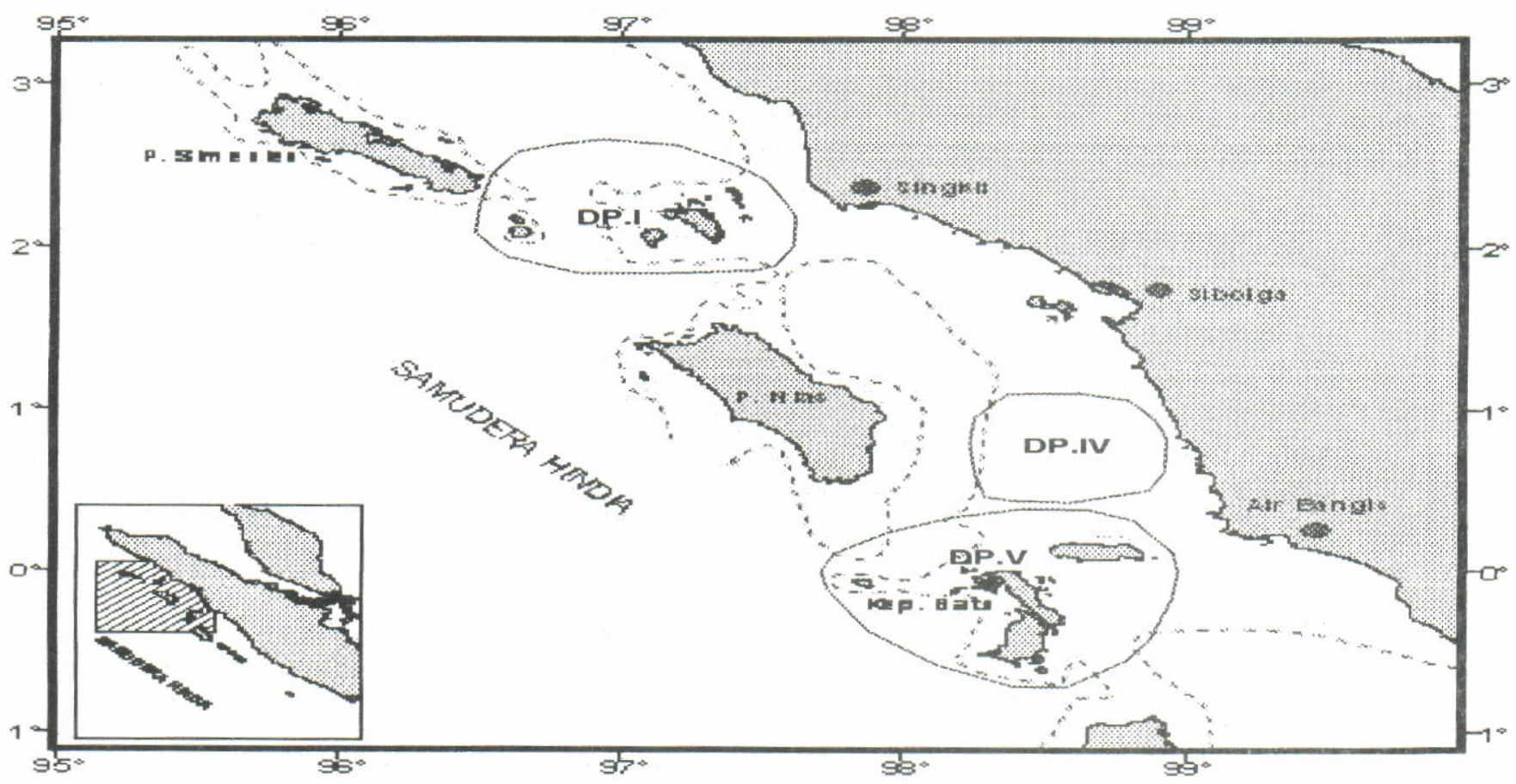

Gambar 5. Daerah Penangkapan (DP) pukat cincin Sibolga di perairan barat Sumatera pada tahun 2003.

Figure 5. $\quad$ Fishing grounds of Sibolga purse seiner in the waters of western Sumatera in year 2003.

Keterangan:

-.---= Isodepth $200 \mathrm{~m}$

$\mathrm{DP}=$ perairan Aceh Selatan

DP IV = perairan Tapanuli Selatan

$\mathrm{DPV}=$ perairan perbatasan Sumatera Utara-Sumatera Barat 
dan layang. Saat ini sumber daya ikan (termasuk layang dan kembung) di kedua daerah penangkapan tersebut dieksploitasi secara intensif oleh armada bagan perahu dan pukat ikan (baca: pukat kucing) asal Sibolga.

Penangkapan ikan cakalang dengan pukat jarang dilakukan terutama di perairan lepas Pantai Mentawai (yang juga merupakan daerah penangkapan ikan cakalang oleh armada pancing tonda asal Padang) serta di perairan lepas Pantai Aceh Selatan sampai perairan Simelue.

\section{Hasil Tangkapan}

Dugaan hasil tangkapan total pukat cincin rapat pada tahun 2003 adalah 25.706,7 ton dengan ratarata tiap bulan 2.142,2 ton dan hasil tangkapan pukat jarang $28.812,9$ ton dengan rata-rata tiap bulan 2 401,1 ton.

\section{a. Hasil tangkapan pukat rapat}

Dari Tabel 1, jenis-jenis ikan pelagis kecil mendominasi $(52,7 \%)$ hasil tangkapan pukat cincin rapat Sibolga yang terdiri atas ikan layang (Decapterus russelli dan D. macrosoma), layang biru (D. macarellus), bentong (Selar crumenophthalmus), banyar (Rastrelliger kanagurta), kembung ( $R$. brachyosoma), selar (Atule mate), siro (Ambligaster sirm), tembang (Sardinella gibbosa), dan japuh (Dussumieria acuta). Persentase ikan kembung (penghuni perairan pantai) paling rendah di antara jenis-jenis ikan pelagis kecil karena daerah penangkapan saat ini sudah mengarah ke perairan oseanik yang berkadar garam tinggi sehingga keberadaan ikan kembung sangat kurang. Beberapa jenis ikan pelagis lainnya menempati $6,4 \%$ yang terdiri atas tetengkek, daun bambu, layur, alu-alu, cumicumi, dan teri. Dua jenis ikan pelagis besar yang tertangkap pukat rapat yaitu tuna dan tongkol menempati $24,7 \%$ sedangkan ikan cakalang hampir tidak ditemukan di dalam hasil tangkapan pukat cincin rapat. Kategori ikan lain-lain terdiri dari jenis-jenis ikan demersal $(5,6 \%)$ serta ikan yang rusak $(10,5 \%)$.

Dibandingkan dengan komposisi hasil tangkapan pukat cincin tahun 1990-1994, komposisi hasil tangkapan pukat cincin rapat tahun 2003 mengalami sedikit perubahan yaitu dengan meningkatnya persentase ikan pelagis besar pada tahun 2003 sekitar 2 kali, dari 12-15\% (tahun 1990-1994) menjadi 24,7\%. Pada tahun 1990-1994 di dalam hasil tangkapan, ikan layang biru terdapat sangat sedikit sedangkan pada tahun 2003 cukup signifikan tertangkap oleh pukat rapat $(1.470,1$ ton, $5,7 \%)$ dan pukat jarang $(104,3$ ton, $0,4 \%)$ diduga karena meluasnya daerah penangkapan pukat cincin rapat. Demikian juga, dengan persentase ikan bentong yang pada tahun $1992-1994$ kurang dari $10 \%$, pada tahun 2003 meningkat menjadi 16,9\% (Tabel 1) karena penyebaran ikan bentong adalah dari perairan pantai sampai ke perairan dengan kedalaman $80 \mathrm{~m}$. (Widodo \& Burhanuddin, 1995).

\section{b. Hasil tangkapan pukat jarang}

Dalam Tabel 2, jenis-jenis ikan pelagis besar mendominasi hasil tangkapan pukat jarang $(76,2 \%)$ terdiri dari jenis-jenis ikan tuna (Thunnus albacares)

Tabel 1. Dugaan hasil tangkapan (ton) dan komposisi hasil tangkapan (\%) pukat cincin rapat Sibolga di perairan barat Sumatera tahun 2003

Table 1. Estimation of yield and catch composition of 1 inch mesh Sibolga purse seine in the waters of western Sumatera in 2003

\begin{tabular}{|c|c|c|c|c|c|c|c|c|c|c|c|c|c|}
\hline & D.spp. & D.mc. & S.c. & R.k. & R.b. & A.m. & A.s. & S.g. & D.a & $\begin{array}{c}\text { Tong- } \\
\text { kol }\end{array}$ & Tuna & $\begin{array}{l}\text { Pela-gis } \\
\text { kecil lain }\end{array}$ & Others \\
\hline Jan & 332,1 & 70,9 & 303,0 & 62,4 & 0,3 & 42,2 & 42,3 & 112,4 & 10,7 & 229,7 & 50,6 & 63,7 & 444,9 \\
\hline Peb & 83,1 & 77,1 & 306,1 & 36,0 & 0,6 & 3,6 & 5,6 & 67,8 & 13,0 & 424,2 & 21,3 & 246,6 & 213,4 \\
\hline Mar & 327,7 & 302,3 & 579,4 & 97,1 & 9,8 & 282,4 & 0,4 & 73,0 & 81,4 & 597,2 & 0,0 & 379,8 & 529,6 \\
\hline Apr & 141,4 & 52,5 & 193,2 & 126,4 & 43,5 & 114,0 & 4,1 & 176,5 & 8,5 & 154,7 & 0,0 & 106,1 & 72,4 \\
\hline Mei & 90,6 & 20,7 & 276,6 & 122,8 & 6,7 & 27,4 & 49,1 & 130,1 & 8,7 & 474,1 & 1,4 & 187,6 & 358,8 \\
\hline Juli & 119,3 & 6,7 & 313,3 & 73,7 & 45,9 & 74,3 & 282,0 & 9,5 & 0,0 & 678,4 & 0,0 & 35,5 & 238,8 \\
\hline Agust & 822,8 & 0,0 & 239,3 & 130,0 & 0,0 & 0,0 & 88,8 & 50,8 & 0,0 & 408,1 & 0,0 & 71,5 & 816,2 \\
\hline Sept & $1.020,1$ & 411,1 & 673,0 & 151,7 & 1,0 & 44,2 & 21,5 & 53,9 & 60,5 & 618,9 & 16,0 & 29,4 & 353,5 \\
\hline Okt & 192,2 & 119,3 & 450,4 & 113,7 & 0,0 & 99,3 & 17,2 & 37,7 & 0,0 & $1,133,9$ & 8,0 & 51,7 & 205,4 \\
\hline Nop & 182,4 & 113,2 & 427,5 & 107,9 & 0,0 & 94,3 & 16,3 & 35,8 & 0,0 & $1,076,3$ & 7,6 & 49,1 & 195,0 \\
\hline Des & 451,9 & 204,9 & 207,3 & 83,9 & 0,0 & 3,2 & 3,5 & 151,3 & 10,6 & 125,4 & 0,0 & 15,8 & 182,8 \\
\hline$\%$ & 14,8 & 5,7 & 16,9 & 4,8 & 0,6 & 3,2 & 2,1 & 3,7 & 0,9 & 24,3 & 0,4 & 6,4 & 16,1 \\
\hline
\end{tabular}

Keterangan:

D.spp.: layang bulat dan layang pipih, D.mc.: layang biru, S.c.: bentong, R.k.: banyar, R.b.: kembung, A.m.: selar, A.s.: siro, S.g.: tembang, $D$.a.: japuh, $D$. spp.: scads, $D$ mc.: mackerel scad., S.c.: bigeye scad, $R . k .:$ Indian mackerel, $R$. b.: short bodied mackerel, A.m.: trevallies, A.s.: spotted sardine, S.g.: fringerscale sardine, and D.a.: rainbow sardine. 
cakalang (Katsuwonus pelamis), dan tongkol (Auxis thazard dan Thunnus tonggo/), sedangkan jenis-jenis ikan pelagis kecil (layang biru, layur, alu-alu, dan banyar) hanya sebagian kecil $(3,1 \%)$. Jenis-jenis ikan lainnya terdiri atas jenis-jenis ikan demersal dan ikan yang rusak. Ikan cakalang yang menempati hampir $70 \%$ dalam hasil tangkapan tampaknya cukup potensial. Lohmeyer (1996) menyatakan bahwa di perairan barat Sumatera meliputi perairan Mentawai, Siberut, dan Nias, ditemukan kelompok-kelompok ikan cakalang di samping ikan tongkol, tenggiri, dan kembung.

Dari Tabel 1 dan 2, pada tiap bulan ikan tongkol lebih banyak tertangkap oleh pukat rapat daripada dengan pukat jarang diduga karena ikan tongkol menempati habitat yang sama dengan ikan pelagis kecil. Ikan tuna walaupun dalam jumlah yang kecil masih dapat tertangkap dengan pukat rapat, sedangkan ikan cakalang hampir tidak tertangkap. Adapun dengan pukat jarang, ikan cakalang tertangkap dalam jumlah yang paling besar (dominan). Ikan layang biru pada tahun 2003 ini lebih banyak tertangkap dengan pukat rapat dibandingkan dengan pukat jarang.

\section{Jumlah Hari Efektif}

Dari proporsi jumlah trip kapal contoh yang mengoperasikan pukat rapat dan jumlah trip kapal contoh yang mengoperasikan pukat jarang, dapat dihitung dugaan jumlah trip pukat rapat dan pukat jarang di Sibolga dan sekitarnya pada tiap bulan. Dugaan jumlah hari efektif pukat rapat dan pukat jarang tiap bulan pada tahun 2003 diperoleh dari hasil kelipatan jumlah trip dengan rata-rata hari efektif per trip kedua jenis pukat tersebut yaitu 5 hari.

Jumlah hari efektif pukat rapat (untuk menangkap ikan pelagis kecil) pada tiap bulan selalu lebih tinggi dari jumlah hari efektif pukat jarang (untuk menangkap ikan pelagis besar) seperti dalam Gambar 6 , sesuai dengan tujuan utama dari pengoperasian pukat cincin Sibolga tahun 2003 adalah menangkap ikan pelagis kecil. Pengoperasian pukat jarang merupakan alternatif jika tidak ditemukan gerombolan ikan pelagis kecil.

Jumlah hari efektif pukat rapat dan pukat jarang bervariasi, dengan puncak pukat rapat terjadi pada

Tabel 2. Dugaan hasil tangkapan (ton) dan komposisi hasil tangkapan (\%) pukat cincin jarang Sibolga di perairan barat Sumatera tahun 2003

Table 2. Estimation of yield (tons) catch composition of 3-4 inch mesh Sibolga purse seine in the waters of western Sumatera in 2003

\begin{tabular}{crrrrrrrrr}
\hline & Tuna & Cakalang & Tongkol & $\begin{array}{c}\text { Layang } \\
\text { biru }\end{array}$ & Alu-alu & Layur & Banyar & Others & Total \\
\hline Jan & 341,7 & $1.953,6$ & 130,1 & 9,3 & 0,0 & 0,7 & 0,0 & 23,3 & $2.458,8$ \\
Feb & 109,9 & $1.696,1$ & 530,8 & 40,0 & 18,8 & 107,6 & 0,0 & 321,3 & $2.824,5$ \\
Mar & 459,0 & $1.187,2$ & 0,0 & 3,2 & 0,0 & 57,2 & 0,0 & 115,9 & $1.822,4$ \\
Apr & 253,6 & $1.385,4$ & 26,0 & 23,7 & 0,2 & 23,1 & 0,0 & 210,4 & $1.922,3$ \\
Mei & 273,2 & $1.492,5$ & 28,0 & 25,5 & 0,3 & 24,8 & 0,0 & 226,7 & $2.071,0$ \\
Jun & 87,2 & 774,2 & 41,4 & 2,6 & 0,0 & 0,0 & 0,0 & 294,2 & $1.199,6$ \\
Juli & 622,8 & 872,9 & 38,2 & 0,0 & 0,0 & 0,0 & 0,0 & 198,7 & $1.732,5$ \\
Ags & 129,1 & $1.483,0$ & 24,5 & 0,0 & 0,0 & 0,0 & 0,0 & 203,9 & $1.840,4$ \\
Sep & 3,5 & $1.365,2$ & 203,2 & 0,0 & 0,0 & 0,0 & 0,0 & 115,0 & $1.686,9$ \\
Okt & 233,4 & $1.982,8$ & 765,5 & 0,0 & 0,0 & 0,0 & 0,0 & 185,4 & $3.408,1$ \\
Nop & 166,4 & $1.413,7$ & 545,8 & 0,0 & 0,0 & 0,0 & 171,9 & 132,2 & $2.430,0$ \\
Des & 242,8 & $1.482,7$ & $\mathbf{7 9 , 3}$ & 16,4 & 16,4 & 162,2 & 0,0 & 62,9 & $2.085,6$ \\
\hline Tot. & $\mathbf{2 . 9 2 2 , 6}$ & $\mathbf{1 7 . 0 8 9 , 4}$ & $\mathbf{2 . 4 1 2 , 6}$ & $\mathbf{1 2 0 , 7}$ & $\mathbf{3 5 , 7}$ & $\mathbf{3 7 5 , 6}$ & $\mathbf{1 7 1 , 9}$ & $\mathbf{6 . 0 2 3 , 5}$ & $\mathbf{2 9 . 4 1 5 , 8}$ \\
\hline \% & $\mathbf{9 , 9}$ & $\mathbf{5 8 , 1}$ & $\mathbf{8 , 2}$ & $\mathbf{0 , 4}$ & $\mathbf{0 , 1}$ & $\mathbf{1 , 3}$ & $\mathbf{0 , 6}$ & $\mathbf{2 0 , 4}$ & $\mathbf{1 0 0 , 0}$ \\
\hline
\end{tabular}

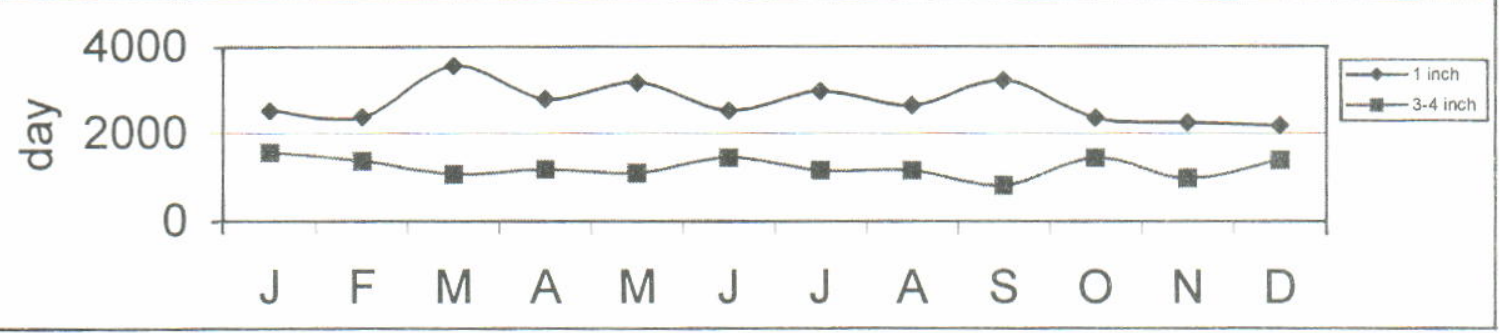

Gambar 6. Jumlah hari efektif pukat rapat dan pukat jarang kapal pukat cincin Sibolga tahun 2003.

Figure 6. Effective fishing day of both 1 inch mesh and 3-4 inch mesh of the Sibolga's purse seiners in year 2003. 
bulan Maret dan September sedangkan puncak pukat jarang pada bulan Januari dan Oktober (Gambar 6). Puncak-puncak hari operasi pukat rapat terjadi bersamaan dengan puncak-puncak hasil tangkapan ikan pelagis kecil terutama ikan layang, layang biru bentong, dan japuh yaitu pada bulan Maret dan September 2003 (Tabel 1). Adapun puncak-puncak jumlah hari efektif pukat jarang bersamaan dengan puncak-puncak hasil tangkapan ikan cakalang yaitu pada bulan Januari dan Oktober 2003 (Tabel 2).

\section{Indeks Kelimpahan Ikan Pelagis Kecil}

Dalam tahun 2003 indeks kelimpahan (cacth rate) ikan pelagis kecil per hari dari pukat cincin rapat sangat bervariasi (Gambar 7), dengan puncak-puncak terjadi pada bulan Maret (awal musim peralihan 1) dan September (musim peralihan 2). Pada periode tahun 1990-1994 puncak kelimpahan rata-rata ikan pelagis kecil terjadi pada musim yang sama yaitu musim peralihan 1 dan musim peralihan 2 diduga karena daerah penangkapan yang sama, walaupun pada tahun 1990-1994 titik berat daerah penangkapan masih terletak di perairan paparan dekat pantai, sedang pada tahun 2003 sudah lebih meluas ke arah lepas pantai. Di Laut Jawa (perairan Matasiri dan Masalembo) puncak musim penangkapan ikan pelagis kecil terjadi pada musim peralihan 2. Adapun di Selat Malaka puncak musim ikan pelagis kecil bervariasi menurut daerah penangkapan; di perairan Banda Aceh pada musim peralihan 1, di Aceh Timur pada musim barat sedangkan di perairan sekitar Pulau Berhala terjadi pada musim peralihan 2 (Suwarso et al., 2004, dan Hariati et al., 2001).

\section{Ukuran Ikan Pelagis Kecil yang Tertangkap Pukat Cincin Rapat}

Dari sebaran frekwensi panjang dan hasil perhitungan kumulatif jenis-jenis ikan pelagis kecil di perairan barat Sumatera pada tahun 2003 (Gambar 8) dan tahun 1993 (Gambar 9) dapat diketahui bahwa ikan layang pipih (Decapterus russelli) dan ikan banyar (Rastrelliger kanagurta) yang tertangkap dengan pukat cincin pada tahun 1993 mempunyai rentang panjang yang lebih sempit dan rata-rata panjang $\left(I_{c}\right)$ yang lebih kecil dari kedua jenis tersebut yang tertangkap pada tahun 2003 (Tabel 3).

Untuk jenis-jenis ikan lainnya seperti layang bulat (D. macrosoma) dan ikan bentong (Selar crumenophthalmus) yang tertangkap pada tahun 2003 mempunyai kisaran panjang yang lebar mencakup ikan kecil $(<10 \mathrm{~cm})$ dan ikan besar $(>=20 \mathrm{~cm})$, kecuali ikan layang biru (D. macarellus) yang tertangkap mulai dari ikan yang berukuran sedang (Tabel 3 ).

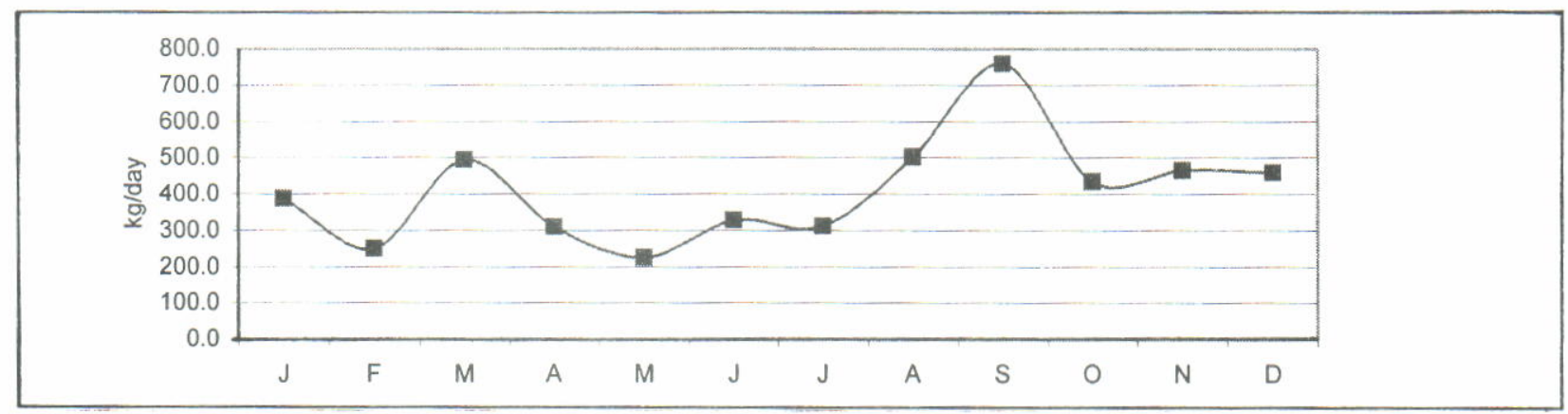

Gambar 7. Indeks kelimpahan ikan pelagis kecil pada tahun 2003 di perairan barat Sumatera.

Figure 7. Cacth rate of smale pelagic in 2003 in the water of western Sumatera.

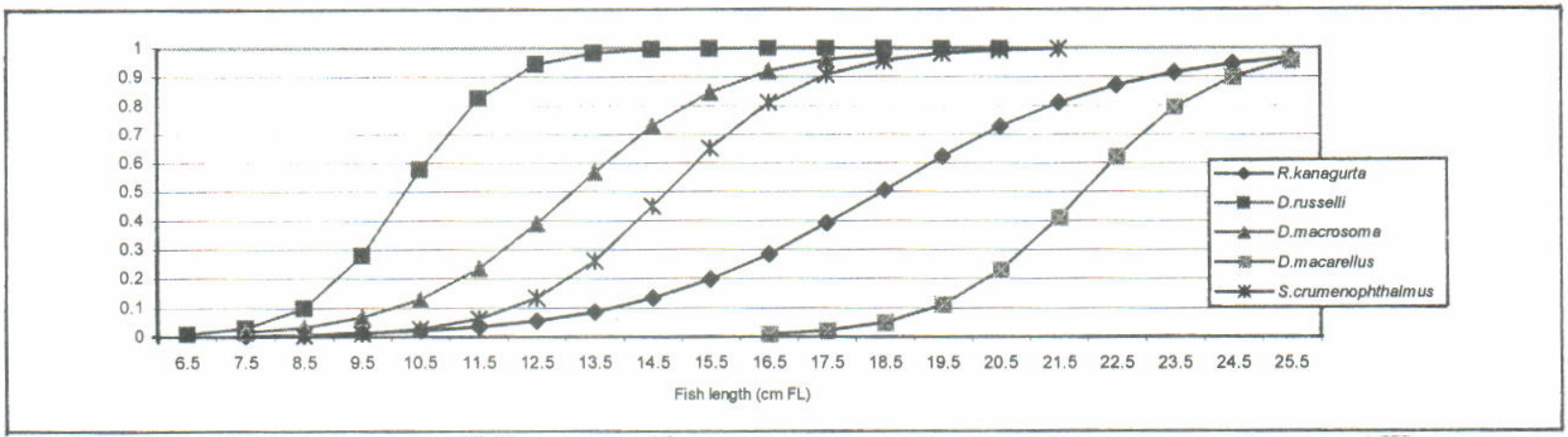

Gambar 8. Kurva logistik ikan pelagis kecil yang tertangkap pukat cincin rapat di perairan barat Sumatera tahun 2003.

Figure 8. Logistic curve of small pelagic fishes caught by the 1 inch mesh purse seine in the waters of western Sumatera in year 2003. 


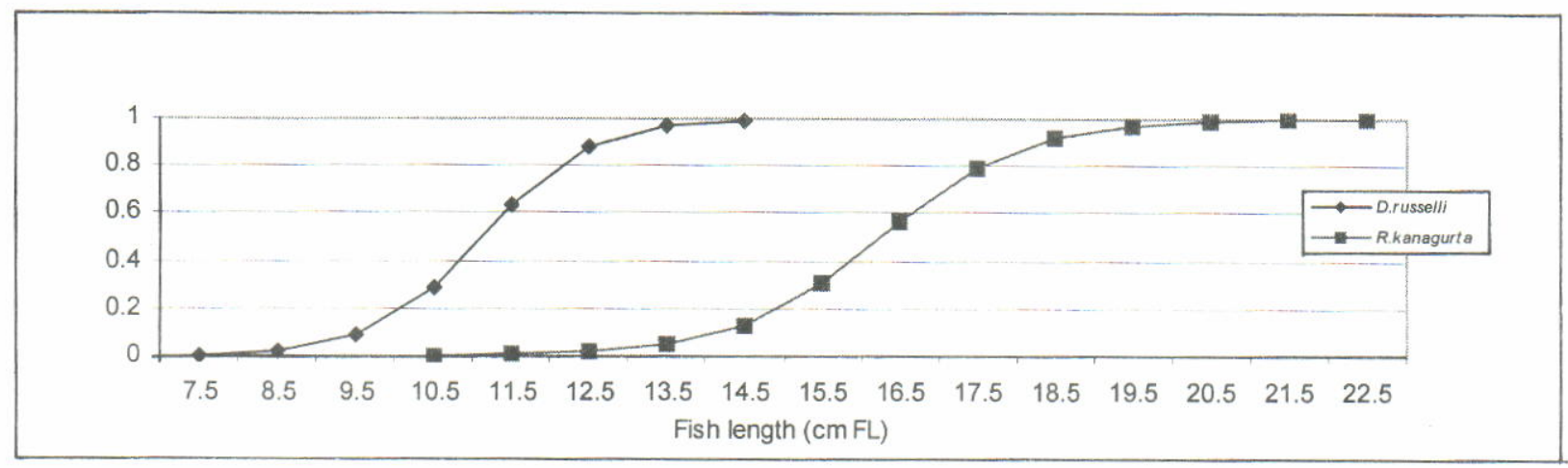

Gambar 9. Kurva logistik ikan pelagis kecil yang tertangkap pukat cincin rapat di perairan barat Sumatera tahun 1993.

Figure 9. Logistic curve of small pelagic fishes caught by the 1 inch mesh purse seine in the waters of western Sumatera in year 1993.

Tabel 3. Kisaran panjang dan $I_{c}$ beberapa spesies ikan pelagis kecil yang tertangkap pukat cincin di perairan barat Sumatera

Table 3. Range of length and $I_{c}$ of small pelagic fishes caught by purse seine in the waters of western Sumatera

\begin{tabular}{|c|c|c|c|c|}
\hline \multirow{2}{*}{ Species } & \multicolumn{2}{|c|}{ Range of length (cm FI) } & \multicolumn{2}{|c|}{$\mathrm{I}_{\mathrm{c}}(\mathrm{cm} \mathrm{FI})$} \\
\hline & 2003 & 1993 & 2003 & 1993 \\
\hline Decapterus russelli & $7-20$ & $7-16$ & 12,8 & 11,1 \\
\hline D. macrosoma & $7-20$ & - & 13,1 & - \\
\hline D. macarellus & $16-26$ & - & 21,9 & - \\
\hline Rastrelliger kanagurta & $7-26$ & $10-23$ & 18,4 & 16,2 \\
\hline Selar crumenophthalmus & $7-21$ & - & 14,7 & - \\
\hline
\end{tabular}

Keterangan: - no data.

Lebih panjangnya rentang kisaran panjang ikan pelagis kecil dan lebih besarnya nilai-nilai $I_{c}$ yang diperoleh dari hasil tangkapan pukat cincin rapat di perairan barat Sumatera pada tahun 2003 dibandingkan dengan pada tahun 1993 (Tabel 3) tidak terlepas dari meluasnya daerah penangkapan pukat cincin rapat. Pada tahun 2003 daerah penangkapan mencapai areal lepas pantai dan cekungan-cekungan laut dalam (Gambar 5), sedangkan pada tahun 1995 daerah penangkapan pukat cincin di barat Sumatera masih terbatas di daerah paparan (Gambar 1).

Di paparan Sunda yaitu di perairan Laut Cina Selatan, ikan yang tertangkap pukat cincin sebagian besar merupakan ikan muda $(14-20 \mathrm{~cm})$ dan tergolong ikan yang reproduktif tidak aktif, meskipun ukurannya rata-rata lebih besar dari ikan pelagis kecil yang tertangkap di perairan Laut Jawa yaitu $13-19 \mathrm{~cm}$ (Atmadja et al., 2001). Hal yang sama ditemukan di perairan barat Sumatera pada tahun 1992-1994, berdasarkan pengamatan terhadap contoh gonad ikan layang betina, umumnya masih pada tahap perkembangan awal (TKG I) dan hampir tidak ditemukan ikan yang matang gonad.

Sebagian dari daur hidup jenis-jenis ikan pelagis kecil terutama ikan banyar adalah di atas paparan, tetapi bila mencapai dewasa (matang gonad) pergi ke perairan yang lebih dalam untuk melakukan pemijahan. Amin et al., (1981) menemukan jenis-jenis ikan karang di perairan barat Sumatera (kurang lebih di sekitar daerah penangkapan pukat cincin) di pinggir paparan. Pada tahun 2003 ada 4 nama lokal ikan banyar berdasarkan ukuran yaitu siluncung yang berukuran kecil sekitar 7-9 cm, kawanan sekitar 10-15 $\mathrm{cm}$, gambolo berukuran sekitar $16-19 \mathrm{~cm}$, dan gambolo karang yang berukuran besar berukuran 20 $\mathrm{cm}$ ke atas. Pada bulan Oktober 2003 di perairan Pulau Pini juga tertangkap ikan banyar betina (contoh) yang berukuran $22-25 \mathrm{~cm}, 100 \%$ dalam kondisi hampir selesai memijah (partially spent). Diduga daerah penangkapan saat ini telah mendekati daerah pemijahan.

Rao (1967) sering menemukan kelompok ikan banyar yang tertangkap di perairan Mangalore India dalam kondisi spent sehingga diduga letak lokasi pemijahan tidak terlalu jauh dari daerah penangkapan, hal demikian juga terjadi di perairan barat Sumatera untuk ikan layang. Pada bulan Oktober 2003 saat indeks kelimpahan turun, diperoleh contoh ikan layang betina $D$. macrosoma $100 \%$ dalam kondisi selesai memijah (TKG 5) dari hasil tangkapan pukat cincin rapat di perairan Pulau Pini. 
Daerah pemijahan ikan pelagis kecil memang di luar jangkauan perikanan pukat cincin. Dengan bertambahnya ukuran tubuh dan gonad, ikan layang bermigrasi ke dasar perairan untuk mengkonsumsi organisme zoobenthos. Dalam kondisi demikian di perairan Mozambique jenis-jenis ikan layang menjadi rentan terhadap pengoperasian demersal trawl (Souza \& Gyesater, 1987; Souza, 1988; dalam Dalzell, 1991). Diduga pengoperasian alat tangkap yang sejenis dengan trawl, seperti pukat ikan, di perairan barat Sumatera di mana terdapat cekungancekungan, juga berbahaya bagi sumber daya ikan pelagis kecil khususnya karena dapat menguras daerah pemijahannya.

\section{KESIMPULAN}

Dari uraian hasil penelitian mengenai perkembangan pemanfaatan sumber daya ikan pelagis kecil di perairan barat Sumatera, dapat ditarik kesimpulan sebagai berikut:

1. Pada tahun $2003,85 \%$ dari jumlah kapal pukat cincin Sibolga terdiri atas kapal dengan ukuran besar (50-130 GT) dan 15\% lainnya berukuran sedang (20-49 GT).

2. Sejak tahun 1985 kapal pukat cincin Sibolga yang berjumlah 48 unit mengalami 2 kali peningkatan, yaitu antara tahun 1985 dan tahun 1990 menjadi 125 unit dan antara tahun 1996 dan tahun 2000 dari 134 unit menjadi 204 unit. Dari tahun 2001 sampai dengan tahun 2003 jumlah kapal turun menjadi 203 unit.

3. Jaring pukat cincin yang dibawa oleh kapal ada 2 macam yaitu pukat rapat (mata jaring 1 inci) untuk menangkap ikan pelagis kecil dan pukat jarang (mata jaring 3-4 inci) untuk menangkap ikan pelagis besar.

4. Daerah penangkapan ikan pelagis kecil masih di wilayah perairan Aceh Selatan, Sumatera Utara sampai ke perbatasan dengan perairan Sumatera Barat tetapi meluas ke lepas pantai yang banyak terdapat cekungan-cekungan laut dalam, sedang daerah penangkapan ikan pelagis besar terpusat di lepas pantai Mentawai. Perairan Pantai Tapanuli Tengah dan barat Sibolga sudah hampir tidak ditempuh pukat cincin lagi. Kedua daerah penangkapan tersebut yang diketahui menghasilkan yuwana dan ikan kembung muda, saat ini menjadi daerah penangkapan jenis-jenis alat tangkap lainnya seperti bagan perahu dan pukat ikan (pukat kucing).

5. Hasil tangkapan pukat rapat selama tahun 2003 didominasi oleh ikan layang $(20,5 \%)$ yang terdiri atas ikan layang bulat (Decapterus macrosoma), layang pipih (D. russelli), dan layang biru $(D$. macarellus). Menyusul ikan bentong (Selar crumenophthalmus, $16,9 \%$ ), ikan tongkol $(24,3 \%)$, dan ikan banyar (Rastrelliger kanagurta), siro (Ambligaster sirm), tembang (Sardinella gibbosa), japuh (Dussumieria acuta), dan selar (Atule mate) masing-masing dalam persentase di bawah $10 \%$.

6. Hasil tangkapan pukat jarang didominasi oleh ikan pelagis besar $(76,2 \%)$, yang terdiri atas ikan cakalang (Katsuwonus pelamis, 58,1\%), tuna (Thunnus albacares, 9,9\%), dan tongkol (Auxis thazard dan Thunnus tonggol, 8,2\%). Jenis ikan pelagis kecil (layur, alu-alu, dan banyar) 2,4\% dan ikan lainnya (jenis-jenis ikan demersal dan ikan yang rusak) sekitar $20,4 \%$.

7. Lebih lebarnya kisaran panjang dan lebih besarnya nilai $I_{c}$ jenis-jenis ikan pelagis kecil yang tertangkap dengan pukat cincin rapat pada tahun 2003 dibandingkan dengan kisaran panjang dan nilai $I_{c}$ pada tahun 1993 diduga karena pada tahun 2003 daerah penangkapan pukat cincin Sibolga tidak hanya di perairan paparan seperti pada tahun 1993 tetapi sudah meluas ke perairan dalam dan cekungancekungan di lepas pantai.

8. Contoh ikan banyar dan ikan layang betina yang tertangkap pada bulan Oktober 2003 dan April 2004 dari perairan perbatasan dengan Sumatera Barat (Pulau Pini dan Pulau Ilik) dalam kondisi selesai memijah (spent). Daerah penangkapan pukat cincin Sibolga diduga telah mendekati daerah pemijahan ikan pelagis kecil. Pengoperasian pukat cincin di dekat daerah pemijahan tidak membahayakan bagi ikan yang akan memijah.

9. Pengoperasian alat tangkap yang sejenis dengan trawl, seperti pukat ikan di perairan barat Sumatera yang penuh dengan cekungan, diduga berbahaya bagi sumber daya ikan pelagis kecil khususnya karena dapat menguras daerah pemijahan.

\section{UCAPAN TERIMA KASIH}

Ucapan terima kasih disampaikan kepada Dinas Kelautan dan Perikanan Kota Sibolga: Ir. Sardiun Simadjuntak, MSc. (Kepala) serta Sdr. Hendra Darmalius, A.Pi. dan Sdr. Sukhairil Pasaribu, S.Pi. Ucapan yang sama disampaikan kepada PT. ASSA Sdr. Dadang Rahmad Ginting (Manajer) dan Sdr. Ali Rachman Tanjung, S.Pi. (Kepala Cold Storage). Atas bantuan dan kerja sama dalam penelitian sumber daya ikan pelagis kecil di perairan barat Sumatera yang berbasis di Sibolga. 


\section{DAFTAR PUSTAKA}

Amin, E. M., H. R. Barus, \& D. Karyana. 1981. Penelitian sumber daya perikanan di perairan sebelah barat dan utara Sumatera menggunakan R/V DR Fridtjof Nansen. Buletin Penelitian Perikanan Vol.I No.3: hal. 321-344.

Atmadja, S. B., E. Wiyono, \& D. Nugroho. 2001. Karakteristik sumber daya ikan pelagis kecil di Laut Cina Selatan dan perkembangan eksploitasinya. Buletin PSP Vol.X No.1. April 2001, hal. 51-64.

Dallzel, P. 1984. Small pelagic fishes. In nearshore marine resources of the South Pacific. Andrew Wright and Lance Hill S. (Eds.): p.117-149.

Hariati, T. 2001. Pemanfaatan ikan pelagis kecil oleh armada pukat cincin Sibolga di perairan barat Sumatera. Pesisir dan Pantai Indonesia VI. Pusat Penelitian dan Pengembangan Oseanologi LIPI: hal. 29-39.

Hariati, T., Suwarso, \& I. G. S. Mertha. 2001a. Pendugaan parameter populasi ikan layang (Decapterus russelli) di perairan pantai barat Sumatera. Pesisir dan Pantai Indonesia VI. Pusat Penelitian dan Pengembangan Oseanologi LIPI: hal. 105-112.

Hariati, T., Suwarso, \& I. G. S. Mertha. 2001b. Analisis frekwensi panjang ikan banyar (Rastrelliger kanagurta) dari perairan Pantai Aceh Selatan, wilayah barat Sumatera. Pesisir dan Pantai Indonesia VI. Pusat Penelitian dan Pengembangan Oseanologi LIPI: hal. 207-215.

Lohmeyer, V. 1996. Narrative \& major result of the Indonesian-German Module (II) of the Jetindofish Project, Aug. 79-July 87. In Baseline studies of biodiversity: The Fish. Res. of Western Indonesia. ICLARM Stud. Rev.: p.77-90.

Merta, I. G. S. M., S. Nurhakim, \& J. Widodo. 1998. Sumber daya perikanan pelagis kecil. Potensi dan Penyebaran Sumber Daya Ikan Laut di Perairan Indonesia. Editor: J. Widodo, K. A. Azis, B. E. Priyono, G. H. Tampubolon, N. Naamin, dan A. Djamali. Komisi Nasional Pengkajian Stok Sumber Daya Ikan Laut-LIPI: hal. 89-105.

Sparre, P. \& S. C. Venema. 1999. Introduksi pengkajian ikan tropis. Buku I: Manual. FAO-Pusat Penelitian dan Pengembangan Perikanan Badan Penelitian dan Pengembangan Pertanian Departemen Pertanian. Edisi bahasa Indonesia: 438 hal.

Sudjastani, T. 1983. Pengembangan usaha perikanan laut di Sumatera. Laporan Penelitian Perikanan Laut. No.28: hal. 1-12.

Suwarso, T. Hariati, B. Sadhotomo, S. B. Atmadja, \& Wudianto. 2004. Musim penangkapan ikan pelagis kecil. Musim Penangkapan Ikan di Indonesia. Balai Riset Perikanan Laut. Pusat Riset Perikanan Tangkap, Badan Riset Perikanan dan Kelautan Departemen Kelautan dan Perikanan, Jakarta: hal. 23-45.

Widodo. J, \& Burhanudin. 1985. Systematics of the small pelagic fish species. In Biodynex. M.Potier and S. Nurhakim as Scientific editors. AARD, Indonesian Ministry of Agriculture-AARD, ORSTOM France, European Union: p.39-48.

Rao, R. V. 1967. Spawning behavior and fecundity of the indian mackerel Rastrelliger kanagurta (Cuvier) at Mangalore. Indian Journal of Fisheries Vol.14 (182): 171-186. 
